(c) American Dairy Science Association, 2002.

\title{
Efficacy of Carbohydrate Sources for Milk Production by Cows Fed Diets Based on Alfalfa Silage ${ }^{1}$
}

\author{
G. A. Broderick, ${ }^{\star}$ D. R. Mertens, ${ }^{*}$ and R. Simons $†$ \\ ${ }^{*}$ Agricultural Research Service, USDA \\ US Dairy Forage Research Center \\ 1925 Linden Drive West, Madison, WI 53706 \\ †Christian Agricultural College, Dronton, The Netherlands
}

\begin{abstract}
The effectiveness of three carbohydrate sources, highmoisture ear corn (HMEC), cracked shelled corn (CSC), and a 50:50 mixture of HMEC plus dried citrus pulp (DCP), fed with or without supplemental rumen-undegraded protein as expeller soybean meal (ESBM), was assessed in 48 multiparous dairy cows. All diets contained (dry mater [DM] basis) $50 \%$ alfalfa silage, $10 \%$ ryegrass silage, $28 \% \mathrm{NDF}$, and one of six concentrates: A) $38 \%$ HMEC; B) $38 \%$ CSC; C) $19 \%$ DCP plus $19 \%$ HMEC; D) 27\% HMEC plus 12\% ESBM; E) $27 \%$ CSC plus $12 \%$ ESBM; or F) $13 \%$ DCP, $13 \%$ HMEC, and $12 \%$ ESBM. Diets A, B, and C averaged 19\% crude protein, of which $53 \%$ was nonprotein nitrogen (NPN), and diets $\mathrm{D}, \mathrm{E}$, and $\mathrm{F}$ averaged $22 \%$ crude protein, of which $40 \%$ was NPN. Cows were fed a high-energy covariate diet for $2 \mathrm{wk}$, blocked into eight groups of six, based on covariate protein yield, then randomly assigned to diets that were fed for $12 \mathrm{wk}$. Feeding ESBM increased DM intake, yields of milk, fat-corrected milk, fat, protein, SNF, and milk and blood urea concentration and decreased weight loss. There were no production differences between HMEC and CSC. However, DM intake, yields of milk, fat-corrected milk, fat, protein, lactose, SNF, and milk SNF content all were lower on the diets containing DCP versus HMEC and CSC. A $6 \times 6$ Latin square trial conducted at the same time with six ruminally cannulated cows showed similar effects of diet on DM intake and milk production. Ruminal ammonia was elevated by ESBM but not ruminal total amino acids and branched-chain volatile fatty acids. Ruminal propionate was highest on HMEC diets and lowest on DCP diets; acetate, butyrate and acetate-to-propionate ratio
\end{abstract}

\footnotetext{
Received September 21, 2001.

Accepted January 24, 2002.

Corresponding author: G. A. Broderick; e-mail: glenb@dfrc. wisc.edu.

${ }^{1}$ Mention of any proprietary product in this paper does not constitute a guarantee or warranty of the product by the USDA or the Agricultural Research Service and does not imply its approval to the exclusion of other products that also may be suitable.
}

were lowest on HMEC diets and highest on DCP diets. These results indicated that, compared to HMEC and CSC, feeding the pectin-rich carbohydrate source DCP altered ruminal fermentation but depressed intake and milk production in lactating cows.

(Key words: alfalfa silage, carbohydrate source, nonprotein N, milk yield)

Abbreviation key: $\mathbf{A S}=$ alfalfa silage, $\mathbf{C S C}=$ cracked shelled corn, $\mathbf{D C P}=$ dried citrus pulp, ESBM $=$ expeller soybean meal, $\mathbf{H C P}=50: 50$ mixture of high-moisture ear corn and dried citrus pulp, HMEC = high-moisture ear corn, $\mathbf{M U N}=$ milk urea $\mathrm{N}$.

\section{INTRODUCTION}

Upon ensiling, a large proportion of the CP in haycrop silages is converted to NPN; typically, 50 to $60 \%$ (Broderick et al., 1990; Luchini et al., 1997) to more than $80 \%$ (Muck, 1987) of the total $\mathrm{N}$ in alfalfa silage (AS) is in the form of NPN. Breakdown of AS true protein to NPN substantially reduces efficiency of CP utilization in lactating cows (Nagel and Broderick, 1992; Broderick, 1995). Feeding carbohydrates that are more extensively fermented in the rumen may improve utilization of the NPN in AS and other hay-crop silages through stimulation of microbial protein synthesis. Owens et al. (1986) summarized data indicating that the proportions of starch digested in the rumen was substantially greater for ensiled high-moisture corn than for cracked corn. Knowlton et al. (1998) reported that ruminal starch digestion averaged $84 \%$ for high-moisture shelled corn and $65 \%$ for dry shelled corn. Increasing ruminal starch digestion increased milk and protein yield but reduced fat yield (Keady et al., 1998; Valadares et al., 2000). In vitro fermentation of citrus pectin gave rise to a ruminal acetate-to-propionate ratio of about 9 and, although it fermented as rapidly as starch, did not depress ruminal $\mathrm{pH}$ (Hatfield and Weimer, 1995). Ben-Ghedalia et al. (1989) found that dried citrus pulp (DCP), a feed with low starch and high pectin content, yielded higher ruminal $\mathrm{pH}$ and increased flow 
of microbial protein from the rumen when fed to replace barley in sheep diets.

The objective of this trial was to compare the effectiveness of three different carbohydrate sources, highmoisture ear corn (HMEC), cracked shelled corn (CSC), and a 50:50 mixture of HMEC and DCP (HCP), for stimulating ruminal $\mathrm{N}$ utilization on a diet high in RDP. If the supplement containing DCP were as effective as those based on corn only, then this would indicate that high pectin sources could be used to replace starchy concentrates without depressing ruminal $\mathrm{pH}$ and acetate supply. Efficacy of carbohydrate sources for stimulating RDP utilization was assessed from the response of lactating dairy cows to a protein supplement rich in RUP, assuming that this response would be inversely related to the value of the carbohydrate source in the basal diet.

\section{MATERIALS AND METHODS}

\section{Trial 1}

Two separate groups of 24 multiparous, lactating Holstein cows (BW, $596 \pm 53 \mathrm{~kg}$; milk yield, $41 \pm 4 \mathrm{~kg} /$ d; parity, $3.2 \pm 1.7$; and DIM, $66 \pm 16$ [mean \pm SD]) were fed a covariate TMR containing (DM basis) $28 \%$ AS, $27 \%$ corn silage, $42 \%$ HMEC, $2 \%$ low solubles fish meal (Sea Lac; Zapata-Haynie Co., Hammond, LA), plus $1 \%$ minerals and vitamins, $16 \% \mathrm{CP}, 28 \% \mathrm{NDF}$, and $1.65 \mathrm{Mcal} / \mathrm{kg}$ NEL $(\mathrm{NRC}, 2001$ ) for a 2 -wk covariate period. After the covariate period and 1-wk transition, cows within each group were blocked into blocks of six based on covariate protein yield because this trait was considered to be most responsive to metabolizable protein supply (NRC, 2001). Within blocks, cows were randomly assigned to one of six TMR diets fed for the following 12-wk. Diets contained (DM basis) $60 \%$ haycrop silage (50\% AS and 10\% ryegrass silage) and $40 \%$ concentrate (Table 1). Three diets contained different carbohydrate sources: HMEC, CSC, or HCP (a 50:50 mixture of HMEC and DCP); urea was added to keep diets isonitrogenous. The other three diets contained the same carbohydrates, except expeller soybean meal [ESBM] SoyPlus; West Central Coop., Ralston, IA) was substituted for 12 percentage units of each carbohydrate source (Table 2), but no urea was added.

Cows were housed in individual tie stalls and had free access to water throughout the trial. Cows were milked twice daily, and individual milk yields were recorded daily during all covariate and experimental periods of the trial. Milk samples were collected at a.m. and p.m. milking midway through wk 2 of both covariate periods and wk 2, 4, 6, 8, 10, and 12 of both experimental periods; each sample was analyzed for fat, total protein, lactose, and SNF by infrared analysis (AgSource, Meno- monie, WI). Milk was deproteinized and analyzed for milk urea N (MUN) by a colorimetric assay (Ekinci and Broderick, 1997). Concentrations and yields of fat, total protein, lactose, and SNF were computed as the weighted means from the a.m. and p.m. milk yields on test days. Yield of 3.5\% FCM was computed as described by Sklan et al. (1992). Mean feed efficiency was computed for each cow by dividing mean daily milk yield by mean daily DMI. Blood was sampled $4 \mathrm{~h}$ after feeding from the coccygeal artery of vein of each cow on the last $\mathrm{d}$ of wk $2,4,6,8,10$, and 12 of each experimental period. Blood was heparinized and stored at $2^{\circ} \mathrm{C}$ for about $2 \mathrm{~h}$, then deproteinized by mixing four volumes of whole blood to one volume of $25 \%$ (wt/vol) trichloroacetic acid. After being held $30 \mathrm{~min}$ at $2{ }^{\circ} \mathrm{C}$, samples were centrifuged $\left(30,000 \times g\right.$ for $15 \mathrm{~min}$ at $\left.2^{\circ} \mathrm{C}\right)$ and supernatants stored at $-20^{\circ} \mathrm{C}$. Deproteinized blood was later thawed and analyzed for glucose and urea (Broderick, 1986). $\mathrm{BW}$ were measured on three consecutive days at the start and end of each 12-wk period of the trial to compute $\mathrm{BW}$ change. BCS, on a scale of 1 to 5 , were the means from estimates made on each cow by three different people every 2 wk of each experimental period.

During covariate and experimental periods, diets were fed for ad libitum intake, and DMI was measured. Feed was offered once daily at about $1100 \mathrm{~h}$, and orts were collected and recorded daily; feeding rate was adjusted daily to yield orts of about 5 to $10 \%$ intake. Weekly composites of AS, ryegrass silage, HMEC, TMR, and orts were prepared from daily samples of about 0.5 $\mathrm{kg}$ that were stored at $-20^{\circ} \mathrm{C}$. Weekly samples of CSC, DCP, ESBM, and urea were collected and stored at 21 to $24^{\circ} \mathrm{C}$. Proportions of dietary DM from each ingredient on an as-fed basis were adjusted weekly based on DM determined by drying weekly composites at $60^{\circ} \mathrm{C}(48$ h) for AS, ryegrass silage, and HMEC and at $105^{\circ} \mathrm{C}$ (AOAC, 1980) for CSC, DCP, ESBM, and urea. These DM data also were used to compute daily DMI. After drying, samples were ground through a 1-mm screen (Wiley mill; Arthur H. Thomas, Philadelphia, PA) and analyzed for $\mathrm{DM}$ at $105^{\circ} \mathrm{C}$, ash and OM (AOAC, 1980) for total $\mathrm{N}$ by Kjeldahl using a copper digestion catalyst (Kjeltabs; Tecator Inc., Herndon, VA [AOAC, 1980]), and for NDF and ADF using heat stable $\alpha$-amylase and $\mathrm{Na}_{2} \mathrm{SO}_{3}$ during NDF extraction (Hintz et al., 1995). Samples of TMR were analyzed for starch and sugar content using the methods of Hall et al. (1999 [T. K. M. Webster, West Virginia Univ., Morgantown]) and for fat content (Dairyland Labs, Arcadia, WI). Samples of ESBM were analyzed for protein degradation rate and estimated escape (RUP) using a ruminal in vitro system (Broderick et al., 1990).

At the end of the trial, the weekly composites of AS, ryegrass silage, and HMEC were thawed, and water 
Table 1. Composition of major feed ingredients. ${ }^{1}$

\begin{tabular}{|c|c|c|c|c|c|c|c|c|c|c|c|c|}
\hline \multirow[b]{2}{*}{ Item } & \multicolumn{2}{|c|}{$\begin{array}{l}\text { Alfalfa } \\
\text { silage }\end{array}$} & \multicolumn{2}{|c|}{$\begin{array}{l}\text { Ryegrass } \\
\text { silage }\end{array}$} & \multicolumn{2}{|c|}{ HMEC } & \multicolumn{2}{|c|}{$\mathrm{CSC}$} & \multicolumn{2}{|c|}{ DCP } & \multicolumn{2}{|c|}{ ESBM } \\
\hline & Mean & $\mathrm{SD}$ & Mean & $\mathrm{SD}$ & Mean & $\mathrm{SD}$ & Mean & $\mathrm{SD}$ & Mean & $\mathrm{SD}$ & Mean & $\mathrm{SD}$ \\
\hline Ash, \% of DM & 14.3 & 0.2 & 9.8 & 1.7 & 1.5 & 0.1 & 2.4 & 2.1 & 6.8 & 2.3 & 6.6 & 0.3 \\
\hline $\mathrm{CP}, \%$ of $\mathrm{DM}$ & 26.2 & 3.4 & 13.1 & 3.4 & 8.2 & 0.6 & 9.4 & 0.7 & 6.2 & 1.1 & 48.2 & 3.1 \\
\hline \multicolumn{13}{|l|}{ Soluble N, } \\
\hline$\%$ of $\mathrm{DM}$ & 2.47 & 0.05 & 1.18 & 0.06 & 0.48 & 0.02 & 0.23 & 0.01 & 0.41 & 0.01 & 0.72 & 0.01 \\
\hline NPN, \% of DM & 2.33 & 0.57 & 1.11 & 0.44 & 0.48 & 0.11 & 0.13 & 0.03 & 0.33 & 0.05 & 0.40 & 0.08 \\
\hline NPN, $\%$ of total N & 55.6 & 13.6 & 53.1 & 20.9 & 36.5 & 8.5 & 8.9 & 2.0 & 33.7 & 4.8 & 5.2 & 1.0 \\
\hline $\mathrm{NDF}, \%$ of $\mathrm{DM}$ & 32.4 & 3.9 & 57.9 & 4.1 & 14.2 & 2.2 & 11.1 & 3.4 & 19.5 & 3.6 & 21.1 & 1.1 \\
\hline \multicolumn{13}{|l|}{ NDF ash, } \\
\hline$\%$ of NDF & 3.14 & 2.13 & 1.87 & 0.80 & 0.29 & 0.48 & 0.13 & 0.42 & 0.08 & 0.44 & 0.60 & 0.72 \\
\hline $\mathrm{ADF}, \%$ of $\mathrm{DM}$ & 24.4 & 0.2 & 32.1 & 1.4 & 5.8 & 1.0 & 2.2 & 0.2 & 16.9 & 0.1 & 8.7 & 0.1 \\
\hline $\mathrm{ADIN}, \%$ of $\mathrm{DM}$ & 0.17 & 0.01 & 0.08 & 0.04 & 0.006 & 0.001 & 0.019 & 0.004 & 0.10 & 0.01 & 0.22 & 0.02 \\
\hline
\end{tabular}

${ }^{1} \mathrm{CSC}=$ Cracked shelled corn; ESBM = expeller soybean meal; DCP = dried citrus pulp; HMEC = high-moisture ear corn.

Table 2. Composition of diets. ${ }^{1}$

\begin{tabular}{|c|c|c|c|c|c|c|}
\hline \multirow[b]{2}{*}{ Item } & \multicolumn{6}{|c|}{$\%$ of DM } \\
\hline & HMEC & $\mathrm{CSC}$ & $\mathrm{HCP}$ & $\begin{array}{l}\text { HMEC } \\
+ \text { ESBM }\end{array}$ & $\begin{array}{l}\text { CSC } \\
+\mathrm{ESBM}\end{array}$ & $\begin{array}{l}\mathrm{HCP} \\
+\mathrm{ESBM}\end{array}$ \\
\hline Alfalfa silage & 50.0 & 50.0 & 50.0 & 50.0 & 50.0 & 50.0 \\
\hline Grass silage & 10.0 & 10.0 & 10.0 & 10.0 & 10.0 & 10.0 \\
\hline High-moisture ear corn & 38.4 & & 19.1 & 26.9 & & 13.4 \\
\hline Cracked shelled corn & $\ldots$ & 38.7 & . & $\ldots$ & 26.9 & \\
\hline Citrus pulp & $\ldots$ & $\ldots$ & 19.1 & $\ldots$ & $\ldots$ & 13.4 \\
\hline Expeller soybean meal & $\ldots$ & $\ldots$ & $\ldots$ & 12.0 & 12.0 & 12.0 \\
\hline Urea & 0.5 & 0.2 & 0.6 & $\ldots$ & $\ldots$ & $\ldots$ \\
\hline Dicalcium phosphate & 0.6 & 0.6 & 0.6 & 0.6 & 0.6 & 0.6 \\
\hline Trace-mineralized salt ${ }^{2}$ & 0.3 & 0.3 & 0.3 & 0.3 & 0.3 & 0.3 \\
\hline Potassium magnesium sulfate ${ }^{3}$ & 0.1 & 0.1 & 0.1 & 0.1 & 0.1 & 0.1 \\
\hline Vitamin premix ${ }^{4}$ & 0.1 & 0.1 & 0.1 & 0.1 & 0.1 & 0.1 \\
\hline \multicolumn{7}{|l|}{ Chemical composition } \\
\hline $\mathrm{CP}, \%$ of $\mathrm{DM}$ & 19.0 & 18.6 & 18.9 & 22.4 & 22.7 & 22.1 \\
\hline Ash, \% of DM & 9.9 & 10.5 & 11.4 & 9.9 & 10.2 & 10.8 \\
\hline Fat, \% of DM & 2.9 & 2.9 & 3.0 & 3.6 & 3.5 & 3.2 \\
\hline $\mathrm{NDIN} \times 6.25, \%$ of $\mathrm{DM}$ & 1.7 & 2.0 & 2.0 & 3.0 & 3.1 & 3.2 \\
\hline Soluble N, \% of DM & 1.8 & 1.5 & 1.8 & 1.6 & 1.5 & 1.6 \\
\hline Soluble N, \% of total N & 58.2 & 51.4 & 59.5 & 43.8 & 41.3 & 44.1 \\
\hline NPN, \% of DM & 1.7 & 1.4 & 1.7 & 1.5 & 1.4 & 1.4 \\
\hline NPN, \% of total N & 55.5 & 47.6 & 56.4 & 40.6 & 37.4 & 40.5 \\
\hline $\mathrm{NDF}, \%$ of DM & 27.4 & 26.2 & 28.4 & 28.3 & 27.4 & 29.0 \\
\hline Sugar, \% of DM & 2.7 & 2.8 & 5.3 & 3.2 & 3.5 & 4.9 \\
\hline Starch, \% of DM & 30.6 & 31.0 & 20.0 & 25.1 & 23.4 & 17.1 \\
\hline $\mathrm{NFC}, \%$ of DM & 42.5 & 43.7 & 40.4 & 38.8 & 39.3 & 38.2 \\
\hline $\mathrm{NE}_{\mathrm{L}} \mathrm{p},{ }^{5} \mathrm{Mcal} / \mathrm{kg}$ & 1.52 & 1.53 & 1.52 & 1.54 & 1.54 & 1.55 \\
\hline
\end{tabular}

${ }^{1} \mathrm{HMEC}=$ High-moisture ear corn; CSC = cracked shelled corn; HCP = high-moisture ear corn plus dried citrus pulp; ESBM = expeller soybean meal.

${ }^{2}$ Provided $27 \mathrm{mg}$ of $\mathrm{Mn}, 27 \mathrm{mg}$ of $\mathrm{Zn}, 17 \mathrm{mg}$ of $\mathrm{Fe}, 7 \mathrm{mg}$ of $\mathrm{Cu}, 0.40 \mathrm{mg}$ of I, $0.30 \mathrm{mg}$ of Se, and $0.10 \mathrm{mg}$ of $\mathrm{Co} / \mathrm{kg}$ of DM.

${ }^{3}$ Dynamate (IMC, Lake Forest, IL) provided $110 \mathrm{mg}$ of $\mathrm{Mg}, 180 \mathrm{mg}$ of K, and $220 \mathrm{mg}$ of S/kg of DM.

${ }^{4}$ Provided 3880 IU of vitamin A, 730 IU of vitamin D, and $0.73 \mathrm{IU}$ of vitamin E/kg of DM.

${ }^{5}$ Computed by discounting dietary energy content based on actual intake (NRC, 2001). 
extracts were prepared (Muck, 1987) from these as well as the weekly samples of CSC, DCP, and ESBM. Extracts were analyzed for total soluble $\mathrm{N}$ and then deproteinized (Muck, 1987) and analyzed for NPN (Muck, 1987) by Kjeldahl as described. Urea $\mathrm{N}$ was assumed to be all NPN. Thawed weekly composites also were dried at $60^{\circ} \mathrm{C}(48 \mathrm{~h})$, ground through the $1-\mathrm{mm}$ screen and composited by mixing equal amounts of DM to obtain samples corresponding to each 4-wk period in each trial. These samples then were analyzed as described above for $\mathrm{DM}$ at $105^{\circ} \mathrm{C}$, ash and $\mathrm{OM}$, for total $\mathrm{N}$, and for NDF and ADF. Mean composition data for the six major feed ingredients and the six TMR are in Tables 1 and 2 , respectively.

\section{Trial 2}

Six multiparous, lactating Holsteins cows (BW, 644 $\pm 42 \mathrm{~kg}$; milk yield, $36 \pm 5 \mathrm{~kg} / \mathrm{d}$; parity, $4.2 \pm 2.1$; and DIM, $143 \pm 21$ [mean \pm SD]) fitted with permanent ruminal cannulae were randomly assigned to a $6 \times 6$ Latin square with 21-d periods and fed the same experimental diets as in trial 1. Mean daily DMI, milk composition, and mean daily yield data were determined as in trial 1 for wk 3 of each period. Milk production data were collected and reported; however, these cows averaged 269 DIM by the end of the trial, and milk yield for one cow was very low $(<10 \mathrm{~kg} / \mathrm{d})$ for the last two periods. However, mean DMI declined only from $23 \mathrm{~kg} /$ $\mathrm{d}$ (period 1) to $19 \mathrm{~kg} / \mathrm{d}$ (period 6) so it was assumed that ruminal data would be similar to that of the 48 cows in trial 1 (mean DMI $=20.6 \mathrm{~kg} / \mathrm{d}$ ). Body weights were measured on three consecutive days at the start and end of each 3-wk period to compute BW change. Body condition was not scored in this trial.

Samples of strained ruminal fluid, taken on d 20 of each period from the ventral sac of the rumen at 0 (just before feeding), 1, 2, 3, 4, 6, 8, and $10 \mathrm{~h}$ after feeding, were prepared by straining rumen contents through two layers of cheesecloth. After $\mathrm{pH}$ was measured, two subsamples were preserved by adding $0.2 \mathrm{ml}$ of $50 \%$ ( vol $/ \mathrm{vol}$ ) $\mathrm{H}_{2} \mathrm{SO}_{4}$ per $10 \mathrm{ml}$ of ruminal fluid for later analysis of $\mathrm{NH}_{3}$ and total free $\mathrm{AA}$, and by adding $5 \mathrm{ml}$ of formic acid per $5 \mathrm{ml}$ of ruminal fluid for later analysis of VFA (Brotz and Shaefer, 1987). These samples were stored at $-20^{\circ} \mathrm{C}$. After the trial, ruminal samples were thawed, centrifuged $\left(15,000 \times g, 4^{\circ} \mathrm{C}, 15 \mathrm{~min}\right)$, and analyzed for $\mathrm{NH}_{3}$ and total free AA (Broderick and Kang, 1980) and for VFA (Brotz and Shaefer, 1987). On d 21 of each period, rumens of all six cows were emptied with subsampling into large, graduated barrels and the volume of total ruminal contents estimated to within 1 $\mathrm{L}$. Total contents were weighed, then transferred to the empty rumen of the next cow that was to receive, during the subsequent period, the diet that yielded those ruminal contents. Samples of whole ruminal contents were mixed, subsamples and then pressed through polyester fabric with $0.105-\mathrm{mm}$ pore size at $1034 \mathrm{kPa}$ with a mechanical press (Hristov and Broderick, 1996) to separate contents into liquids (solubles and small feed particles) and solids (Faichney, 1986). These liquids and solids were weighed to estimate the relative proportions in whole ruminal contents. Ruminal emptying, sampling, and transfer of contents were completed for all six cows in about $1.5 \mathrm{~h}$.

\section{Statistical Analysis}

All statistical analyses were done using the general linear models procedure of SAS (1989). Significance was declared at $P \leq 0.05$ in trial 1 and at $P \leq 0.10$ in trial 2 . In trial 1 , a single mean was computed for each cow for each production trait, and data were analyzed using a model that included the covariate value for that trait as well as diet, block, group (1 or 2 ), block $\times$ diet, and group $\times$ diet interactions. No block $\times \operatorname{diet}(P \geq 0.21)$ interactions were significant. Group $\times$ diet interaction for MUN approached significance $(P=0.09)$; no other group $\times$ diet interaction was significant $(P \geq 0.29)$. Body weight change, MUN, and blood urea and glucose were analyzed with the same model except without covariate. Orthogonal contrasts were used to compare effects of: 1 ) ESBM addition versus no supplement, 2) HMEC versus CSC, 3) HMEC versus HCP, 4) CSC versus HCP, and 5) ESBM addition on HMEC and CSC versus ESBM addition on HCP. Orthogonal contrast 5 was done to assess the relative response of production traits when ESBM supplemented the corn-based diets (HMEC and CSC) versus the response when it supplemented the pectin-based diet (HCP). A significant interaction would indicate that the response to RUP from ESBM was not parallel and thus different. All data from Trial 2 were analyzed as a $6 \times 6$ Latin square using a model that included diet, cow, and period. The same five orthogonal contrasts described above also were used.

\section{RESULTS AND DISCUSSION}

\section{Trial 1}

The AS fed during the trials was very high in total $\mathrm{CP}$ and very low in NDF (Table 1). Therefore, it was necessary to dilute the AS with ryegrass silage (Table 1) to maintain normal dietary NDF without excessive $\mathrm{CP}$ contents in the three basal diets (before supplementation with ESBM). Otherwise, CP, soluble $\mathrm{N}$ and NPN, and NDF contents of the major dietary ingredients were within normal ranges for these feedstuffs (NRC, 2001). High NPN contents are typical for AS (Luchini et al., 
Table 3. Effect of feeding concentrate as high-moisture ear corn, cracked shelled corn, or high-moisture ear corn plus dried citrus pulp, with or without supplemental expeller soybean meal, on animal production in trial $1 .^{1}$

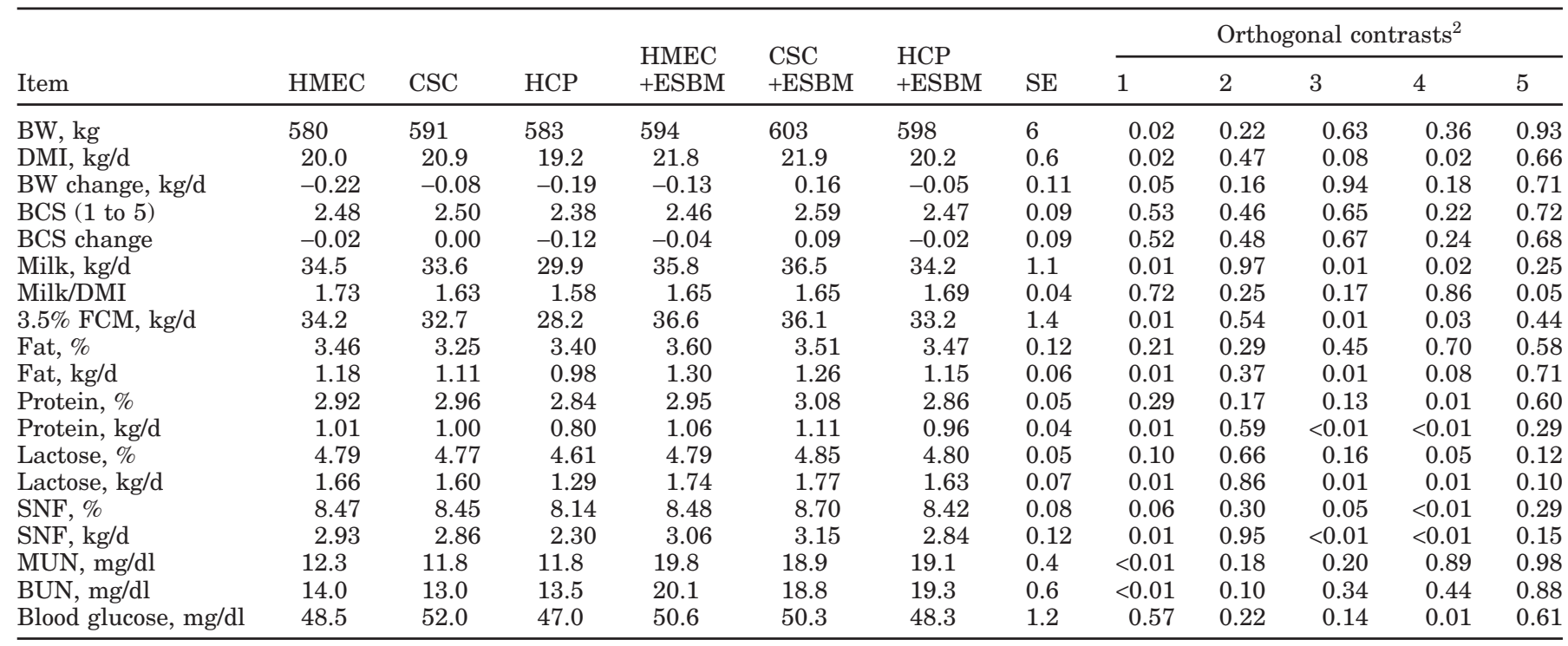

${ }^{1} \mathrm{BUN}=$ Blood urea $\mathrm{N}$; CSC = cracked shelled corn; ESBM = expeller soybean meal; HCP = high-moisture ear corn plus dried citrus pulp; HMEC = high-moisture ear corn; MUN = milk urea $\mathrm{N}$.

${ }^{2}$ Probability of significant orthogonal contrasts. Effects tested using orthogonal contrasts were 1) ESBM vs. no supplement, 2) HMEC vs. CSC, 3) HMEC vs. HCP, 4) CSC vs. HCP, and 5) ESBM on HMEC and CSC vs. ESBM on HCP (the relative effect of ESBM supplementation on HMEC and CSC vs. that on HCP).

1997) and ryegrass silage (McDonald et al., 1991). Soluble $\mathrm{N}$ content of the six TMR ranged from 41 to $60 \%$ of total $\mathrm{N}$, which approximates to protein fraction $\mathrm{A}$ (NRC, 2001)and from 1.50 to $1.80 \%$ of dietary DM (Table 2). The NPN content of the TMR ranged from 37 to $56 \%$ of total N. Together, the two hay-crop silages contributed 75 to $90 \%$ of the soluble $\mathrm{N}$ and 75 to $94 \%$ of the NPN in the six TMR. Urea was added to diets A to C in an attempt to make these TMR isonitrogenous. Urea accounted for 6 to $14 \%$ of the soluble N and NPN and from 3 to $8 \%$ of the $\mathrm{CP}$ equivalent in those diets. The three basal diets contained 26 to $28 \% \mathrm{NDF}$ and an estimated 1.52 to $1.53 \mathrm{Mcal} \mathrm{NE} / \mathrm{p} / \mathrm{kg}\left(\mathrm{NE}_{\mathrm{L}}\right.$ computed at the actual DMI of the trial [NRC, 2001]). The ESBM fed in this trial had a mean estimated RUP values of $57 \%(\mathrm{SD}=7$ ), typical for this protein source (NRC, 2001). Replacing an average $31 \%$ of carbohydrate DM with ESBM increased dietary RUP but had little effect on energy content: NDF was increased about $1 \%$, but computed $\mathrm{NE}_{\mathrm{L}} \mathrm{p}$ was not reduced (Table 2) because of the fat added with ESBM (NRC, 2001).

Feeding ESBM improved intake and milk production (Table 3 , contrast 1$)$. There were increases $(P \leq 0.05)$ in DMI, BW, and BW change, and yields of milk, $3.5 \%$ FCM, and all-milk components, plus a trend for increased milk SNF content, with ESBM supplementation. This result was not unexpected because, although the basal diets had high concentrations of total CP (Table 2), on average $56 \%$ of this CP was supplied as NPN.
Feeding ESBM reduced this proportion to $40 \%$ and increased RUP supply. Because urea intake on basal diets A to $\mathrm{C}$ ranged from 43 to $118 \mathrm{~g} / \mathrm{d}$, and no urea was added in diets $\mathrm{D}$ to $\mathrm{F}$, it is possible that removal of urea from the diet may have accounted for some of the apparent effect of ESBM supplementation. There is disagreement in the literature about whether feeding these amounts of urea would depress production of dairy cows. Earlier, no effect on production was observed when cows were fed $380 \mathrm{~g} / \mathrm{d}$ of urea in diets with $15.6 \%$ total CP, but both DMI and milk yield were reduced when cows were fed $450 \mathrm{~g} / \mathrm{d}$ of urea in diets containing $16.3 \%$ total CP (Broderick et al., 1993). Choung et al. (1990) reported that two daily intraruminal doses of urea sufficient to increase dietary CP equivalent to $\geq 17 \%$ (DM basis) depressed DMI. Tolkamp et al. (1998) found that adding $0.7 \%$ urea to the diet caused preferential selection of the $16 \% \mathrm{CP}$ diet when cows were given the choice between two urea-containing diets with either 22 or $16 \%$ total CP. However, a second study (Tolkamp et al., 1998) showed that DMI and milk yield were equal, with no diet preference, when cows were given free access to three diets containing $0.5,0.8$, or $1.2 \%$ urea, but with equal contents of total soluble protein. In the present trial, intake of NPN was similar with and without ESBM (average NPN intake $=319 \mathrm{~g} /$ $\mathrm{d}$ on diets $\mathrm{A}$ to $\mathrm{C}$ and $300 \mathrm{~g} / \mathrm{d}$ on diets $\mathrm{D}$ to $\mathrm{F}$ ). Moreover, MUN averaged only $12 \mathrm{mg} / \mathrm{dl}$ on diets A to C, which were low to normal concentrations (Broderick and Clay- 
ton, 1997), despite relatively high intakes of CP and NPN. Under the conditions of our experiment, the effects of ESBM feeding appeared to be due to greater RUP supply rather than due to removal of negative effects from urea feeding. Blood urea N and MUN concentrations were increased 6 and $7 \mathrm{mg} / \mathrm{dl}$ with the addition of the 3.6\% units of dietary CP from ESBM. Supplementation with any $\mathrm{CP}$ source regardless of ruminal degradability will increase MUN and blood urea and, although there was a substantial elevation of urea in body water in this trial, the increases were only about half of those predicted from the amount of additional CP fed (Broderick and Clayton, 1997). Milk protein yield averaged $113 \mathrm{~g} / \mathrm{d}$ more with ESBM supplementation, so the lower inflection in urea concentration may be partly attributed to increased protein secretion. However, milk protein accounted for only $11 \%$ of the additional intake of dietary $\mathrm{N}$.

No other production traits were different $(P \geq 0.10)$ between treatments HMEC and CSC (Table 3, contrast 2). The HMEC and CSC carbohydrate sources both gave rise to greater DMI and production of milk, FCM, fat, protein, lactose, and SNF, and greater milk lactose and blood glucose concentrations than treatment HCP (Table 3 , contrasts 3 and 4), which was half DCP and half HMEC. BCS were not influenced by diet. Greater feed intake likely accounted for much or most of the differences in production. However, there was greater than expected energy availability from HMEC. The NRC (2001) assigned similar $\mathrm{NE}_{\mathrm{L}} \mathrm{p}$ (at $3 \times$ and $4 \times$ maintenance) for CSC and ground HMEC, but the HMEC fed in the present trials was not ground. Grinding HMEC was found to increase DM and OM digestibility $5.4 \%$ for a ration containing $42 \%$ HMEC (Ekinci and Broderick, 1997), equivalent to a $13 \%$ difference in DE between ground and unground HMEC. This suggested that $\mathrm{NE}_{\mathrm{L}} \mathrm{p}$ should have been greater for CSC than the unground HMEC. That animal performance was actually comparable on HMEC and CSC may have reflected effects of carbohydrate source on site of digestion. Owens et al. (1986) summarized data indicating that the proportions of starch intake digested in the rumen, small intestine, and large intestine of cattle, were, respectively, 69, 12, and 8\% (total 88\%) for cracked corn and 86,6 , and $1 \%$ (total 95\%) for ensiled high moisture corn. Elizalde et al. (1999) found that these proportions in $338-\mathrm{kg}$ steers averaged, respectively, 49, 32, and $15 \%$ (total 96\%) when cracked shelled corn was fed at 0.4 to $1.2 \%$ of BW to supplement fresh alfalfa fed ad libitum; these proportions were not influenced by the level of cracked corn feeding. Knowlton et al. (1998) observed that ruminal starch digestion averaged $84 \%$ for highmoisture shelled corn and $65 \%$ for dry shelled corn and was not different when either grain was fed in rolled or ground form. It seems probable that, in the present study, HMEC contributed more ruminally fermented carbohydrates that CSC, with the latter supplying more postruminally digested starch.

Dried citrus pulp is a high pectin feed that may serve as an effective energy source without the adverse influences on ruminal fermentation that occur with starch concentrates. Replacing dietary barley with DCP in sheep increased ruminal $\mathrm{pH}$ and microbial protein flow (Ben-Ghedalia et al., 1989). Replacing about half of the dry, ground ear corn in the diet with DCP had no significant effects on intake or feed efficiency in fattening beef steers (Peacock and Kirk, 1959), whereas replacing all of the dietary barley with a mixture of DCP and dried beet pulp improved DMI and weight gain in young Friesian bull calves (Williams et al., 1987). Milk production was unchanged in lactating ewes with partial replacement of dietary corn, barley, and wheat middlings with DCP (Fegeros et al., 1995). Van Horn et al. (1975) reported that DCP served as an effective concentrate source in lactating dairy cows averaging 18 to $20 \mathrm{~kg} / \mathrm{d}$ of milk. However, Sutton et al. (1987) observed that "fibrous" concentrates (citrus pulp, sugar-beet pulp, and wheat feed) were generally less effective than "starchy" concentrates (barley, wheat, and cassava) for supporting the yields of milk, protein, and lactose. Moreover, Solomon et al. (2000) found that DMI and milk protein content and yield were greater in lactating cows fed concentrate as $2 / 3 \mathrm{CSC}$ and $1 / 3 \mathrm{DCP}$ than in cows fed concentrate as 1/3 CSC and 2/3 DCP. Leiva et al. (2000) also observed that milk protein content and yield were depressed on a high-DCP diet despite no changes in DMI. Our results were consistent with these latter reports in that, compared to the HMEC and CSC diets, $50 \%$ dilution of HMEC with DCP decreased $(P \leq 0.03)$ yields of milk, FCM, protein and lactose, and SNF (Table 3 , contrasts 3 and 4 ). This dietary change also reduced or tended to reduce DMI $(P=0.08$ and 0.02 for contrasts 3 and 4$)$ and fat yield $(P=0.01$ and 0.08 for contrasts 3 and 4).

In a few cases, ESBM supplementation appeared to give rise to greater-than-average response on HCP than on the other two carbohydrates. Although the effect of ESBM on HCP was not different from that on HMEC and CSC (Table 3, contrast 5) for yield of milk ( $P=$ $0.25)$, FCM $(P=0.44)$, and protein $(P=0.29)$, effect of ESBM on HCP versus the other carbohydrate sources approached significance for lactose yield $(P=0.10)$. The large numeric response of lactose secretion to ESBM addition may be explained by a greater supply of absorbed amino acids being available for gluconeogenesis (Danfaer, 1994).Although blood glucose concentration was lower on HCP than CSC (Table 3, contrast 4), blood glucose did not respond to $\operatorname{ESBM}(P=0.61)$ in the same 
Table 4. Effect of feeding concentrate as high-moisture ear corn, cracked shelled corn, or high-moisture ear corn plus dried citrus pulp, with or without supplemental expeller soybean meal, on animal production in trial $2 .{ }^{1}$

\begin{tabular}{|c|c|c|c|c|c|c|c|c|c|c|c|c|}
\hline \multirow[b]{2}{*}{ Item } & \multirow[b]{2}{*}{ HMEC } & \multirow[b]{2}{*}{$\mathrm{CSC}$} & \multirow[b]{2}{*}{$\mathrm{HCP}$} & \multirow{2}{*}{$\begin{array}{l}\text { HMEC } \\
+ \text { ESBM }\end{array}$} & \multirow{2}{*}{$\begin{array}{l}\text { CSC } \\
+\mathrm{ESBM}\end{array}$} & \multirow{2}{*}{$\begin{array}{l}\text { HCP } \\
+\mathrm{ESBM}\end{array}$} & \multirow[b]{2}{*}{$\mathrm{SE}$} & \multicolumn{5}{|c|}{ Orthogonal contrasts ${ }^{2}$} \\
\hline & & & & & & & & 1 & 2 & 3 & 4 & 5 \\
\hline $\mathrm{DMI}, \mathrm{kg} / \mathrm{d}$ & 21.2 & 21.5 & 19.6 & 22.4 & 23.2 & 21.9 & 0.4 & $<0.01$ & 0.29 & 0.02 & $<0.01$ & 0.27 \\
\hline Milk, kg/d & 27.2 & 27.7 & 25.8 & 29.3 & 30.8 & 29.5 & 0.8 & $<0.01$ & 0.23 & 0.49 & 0.07 & 0.47 \\
\hline Milk/DMI & 1.27 & 1.29 & 1.31 & 1.31 & 1.32 & 1.35 & 0.03 & 0.39 & 0.61 & 0.21 & 0.44 & 0.91 \\
\hline $3.5 \% \mathrm{FCM}, \mathrm{kg} / \mathrm{d}$ & 28.7 & 28.1 & 26.8 & 28.3 & 31.0 & 28.5 & 1.6 & 0.34 & 0.53 & 0.59 & 0.25 & 0.88 \\
\hline Fat, \% & 3.73 & 3.59 & 3.73 & 3.47 & 3.68 & 3.39 & 0.16 & 0.24 & 0.85 & 0.81 & 0.67 & 0.39 \\
\hline Protein, kg/d & 0.88 & 0.91 & 0.78 & 0.90 & 0.97 & 0.88 & 0.04 & 0.10 & 0.25 & 0.17 & $<0.01$ & 0.43 \\
\hline Lactose, $\%$ & 4.79 & 4.77 & 4.71 & 4.81 & 4.88 & 4.78 & 0.03 & 0.04 & 0.46 & 0.10 & 0.02 & 0.87 \\
\hline Lactose, kg/d & 1.32 & 1.32 & 1.21 & 1.37 & 1.49 & 1.39 & 0.07 & 0.04 & 0.45 & 0.51 & 0.16 & 0.54 \\
\hline $\mathrm{SNF}, \%$ & 8.76 & 8.80 & 8.51 & 8.75 & 8.86 & 8.56 & 0.08 & 0.68 & 0.35 & 0.02 & $<0.01$ & 0.84 \\
\hline $\mathrm{SNF}, \mathrm{kg} / \mathrm{d}$ & 2.41 & 2.43 & 2.18 & 2.49 & 2.69 & 2.49 & 0.12 & 0.05 & 0.36 & 0.36 & 0.08 & 0.51 \\
\hline MUN, mg/dl & 11.3 & 13.9 & 10.5 & 19.3 & 18.8 & 20.3 & 0.7 & $<0.01$ & 0.16 & 0.90 & 0.20 & 0.02 \\
\hline BUN, mg/dl & 13.9 & 15.5 & 13.5 & 20.7 & 19.8 & 21.1 & 0.8 & $<0.01$ & 0.67 & 0.98 & 0.66 & 0.15 \\
\hline
\end{tabular}

${ }^{1} \mathrm{BUN}=$ Blood urea $\mathrm{N}$; CSC = cracked shelled corn; ESBM = expeller soybean meal; HCP = high-moisture ear corn plus dried citrus pulp; HMEC = high-moisture ear corn; MUN = milk urea $\mathrm{N}$.

${ }^{2}$ Probability of significant orthogonal contrasts. Effects tested using orthogonal contrasts were 1) ESBM vs. no supplement, 2) HMEC vs. CSC, 3) HMEC vs. HCP, 4) CSC vs. HCP, and 5) ESBM on HMEC and CSC vs. ESBM on HCP (the relative effect of ESBM supplementation on HMEC and CSC vs. that on HCP).

manner as lactose yield. However, blood glucose turnover, rather than concentration, is a more reliable indicator of glucose supply to the mammary gland for lactose synthesis (Thilsted, 1985). There was an increase $(P=0.05)$ in milk yield/DMI with ESBM for HCP versus that for HMEC and CSC. This was related to the relative changes in DMI and milk yield: DMI and milk yield increased (with ESBM supplementation) 1.9 and 1.5 $\mathrm{kg} / \mathrm{d}$ for HMEC, 1.0 and $2.6 \mathrm{~kg} / \mathrm{d}$ for CSC, and 1.0 and $4.3 \mathrm{~kg} / \mathrm{d}$ for HCP. Supplementing with ESBM reduced BW loss on all three carbohydrates, so nutrient supply from tissue mobilization likely was similar among treatments.

\section{Trial 2}

Production data are reported from this trial (Table 4) even though cows were in late lactation. As in trial 1, DMI and BW change were greater with ESBM supplementation (contrast 1) and greater on HMEC and CSC than on HCP (contrasts 3 and 4). Milk yield/DMI, fat content, and yield of FCM and fat was unaffected by diet, but ESBM feeding (contrast 1) increased yield of milk, protein, lactose, and SNF as in Trial 1. There were, however, several differences between trials in the response patterns. In trial 2 , carbohydrate source (contrasts 2,3 , and 4 ) did not affect lactose yield ( $P \geq$ 0.16 ) and, although yields of milk, protein, and SNF were not different on HMEC versus HCP (contrast 3), all three yield traits were greater on CSC versus HCP (contrast 4), as in trial 1. Effects of diet on MUN and blood urea were similar for both trials, but blood glucose appeared to behave differently. However, blood glucose concentrations were greater on trial 2 (mean $=57 \mathrm{mg} /$ dl) than on trial 1 (mean $=49 \mathrm{mg} / \mathrm{dl})$, and insulin levels and glucose turnover were not studied in either trial.

Treatment responses were similar for ruminal $\mathrm{pH}$ and $\mathrm{NH}_{3}$ (Table 5): $\mathrm{pH}$ and, not surprisingly, $\mathrm{NH}_{3}$ were elevated with ESBM feeding (contrast 1), lower on HMEC than on CSC (contrast 2), and higher on CSC than on HCP (contrast 4). The similar patterns can be partly explained by buffering effects of $\mathrm{NH}_{3}$ on ruminal $\mathrm{pH}$; however, both lower $\mathrm{pH}$ and $\mathrm{NH}_{3}$ on HMEC suggested that greater ruminal fermentation and microbial protein synthesis may have occurred on those diets. Without ESBM addition, ruminal $\mathrm{pH}$ and $\mathrm{NH}_{3}$ were lower on HMEC than on CSC and HCP during most of the 10 -h period after feeding (Figure $1 \mathrm{a}$ and $\mathrm{b}$ ); that pattern was less apparent after ESBM supplementation. Total VFA concentrations were not consistent with $\mathrm{pH}$ values: total VFA were lower on HMEC (contrast 3) and CSC (contrast 4) diets than on HCP. Ruminal VFA concentrations are the net result of production and absorption and do not necessarily reflect fermentation rates (Dijkstra et al., 1993). Moreover, the range of total VFA concentrations was narrow, from only 101 to 108 $\mathrm{m} M$, and these small changes may not be biologically important. In previous studies on HMEC processing, significant effects of diet on total VFA were not detected with similar numbers of observations when concentrations ranged from 137 to $148 \mathrm{mM}$ (Ekinci and Broderick, 1997). 
Table 5. Effect of feeding concentrate as high-moisture ear corn, cracked shelled corn, or high-moisture ear corn plus dried citrus pulp, with or without supplemental expeller soybean meal, on ruminal traits in trial $2{ }^{1}$

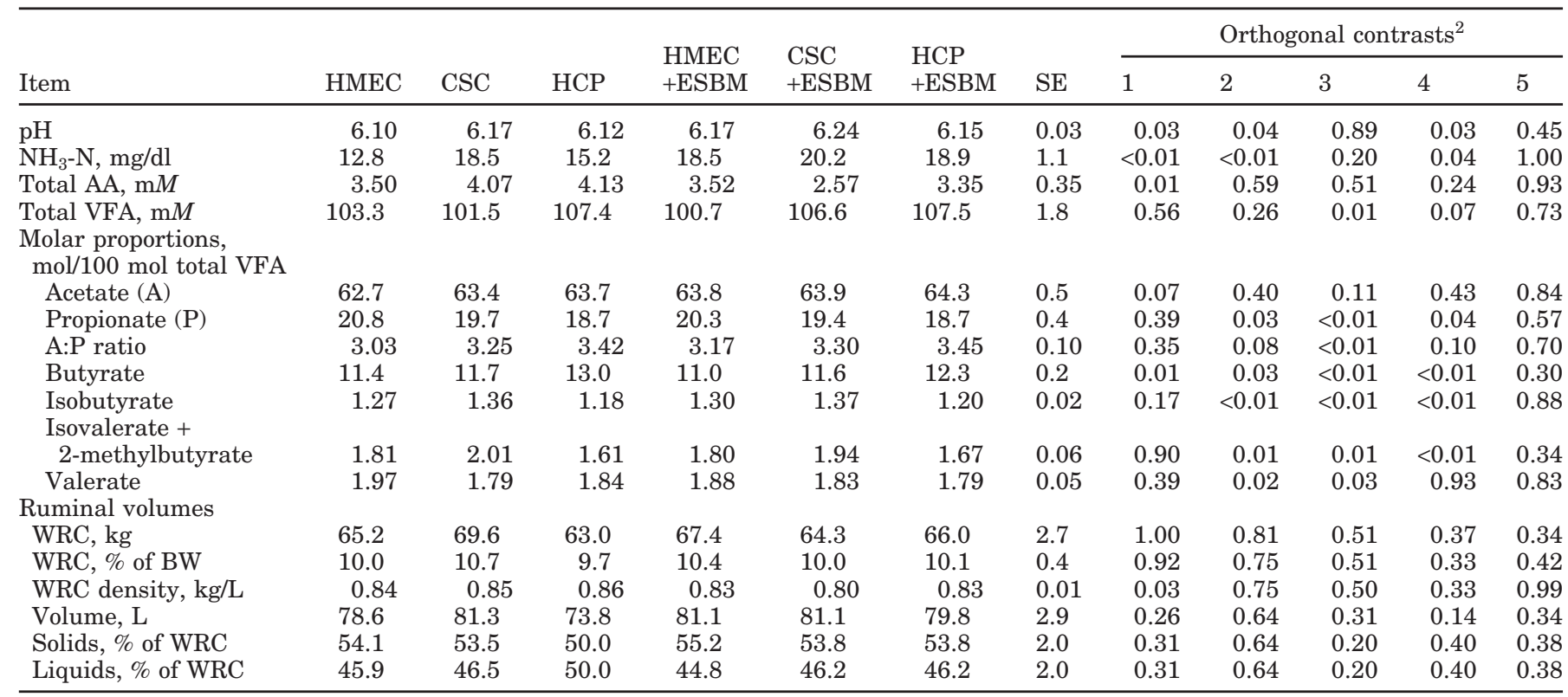

${ }^{1} \mathrm{CSC}=$ Cracked shelled corn; ESBM = expeller soybean meal; HCP = high-moisture ear corn plus dried citrus pulp; HMEC = high-moisture ear corn; WRC $=$ whole ruminal contents.

${ }^{2}$ Probability of orthogonal contrasts. Effects tested using orthogonal contrasts were 1) ESBM vs. no supplement, 2) HMEC vs. CSC, 3) HMEC vs. HCP, 4) CSC vs. HCP, and 5) ESBM on HMEC and CSC vs. ESBM on HCP (the relative effect of ESBM supplementation on HMEC and CSC vs. that on HCP).

Molar proportions of acetate were increased and butyrate reduced with ESBM feeding (Table 5, contrast 1 ), possibly reflecting a small but significant reduction in acetate condensation to butyrate with greater $\mathrm{CP}$ intake. Molar proportion of propionate was highest and molar proportion of butyrate and acetate-to-propionate ratio were lowest on HMEC than on other carbohydrates (contrasts 2 and 3) and lower on CSC than on HCP (contrast 4). Lower propionate and higher butyrate and acetate-to-propionate ratio were consistent with reduced ruminal starch fermentation (Crocker et al., 1998) on HCP. Molar proportions of ruminal valerate were higher on the HMEC diets (contrasts 2 and 3); Crocker et al. (1998) also reported that valerate increased with ruminal starch fermentation. Much of the carbohydrate in DCP, beet pulp, and similar feeds is present as pectin (Ben-Ghedalia et al., 1989); pectic substances are readily fermented, and their inclusion in the diet may increase ruminal acetate formation (Hatfield and Weimer, 1995). The small shifts to greater acetate, butyrate, and acetate-to-propionate ratio observed on the HCP diets were consistent with increased acetate production. However, Sutton et al. (1987) did not find any changes in milk fat content or yield with feeding various "fibrous" concentrates including DCP. Isobutyrate and isovalerate plus 2-methyl butyrate are branched-chain VFA formed from microbial catabolism of branched-chain AA and are important growth factors for cellulolytic bacteria (Hoover, 1986). It is not known why molar proportions of the branched-chain VFA were lower on HMEC than on CSC (contrast 2) and lower on HCP than on either HMEC (contrast 3) or CSC (contrast 4). Overall $\mathrm{NH}_{3}$ and VFA patterns observed in trial 2 suggested that carbohydrate fermentation declined in the order HMEC > CSC > HCP, results that may be explained partly by differences in site of carbohydrate digestion among these diets that were discussed earlier. That molar proportions of branched-chain VFA were not influenced-and total AA concentrations were actually reduced-with ESBM feeding (contrast 1) probably reflected the low ruminal degradability of this protein source. Generally, ruminal total AA concentrations were greater without ESBM supplementation during most of the 10-h period after feeding (Figure 1c). Relatively small differences in ruminal $\mathrm{NH}_{3}$ but large differences in MUN and blood urea with and without feeding of ESBM indicated that metabolizable protein from RUP was largely catabolized with the $\mathrm{N}$ being excreted in the urine.

No differences were detected among the six diets in the mass or volume of whole ruminal contents or in the proportions of liquids and solids separated using standard filtration mesh and pressure (Table 5). A small effect of ESBM feeding on density of whole rumi- 


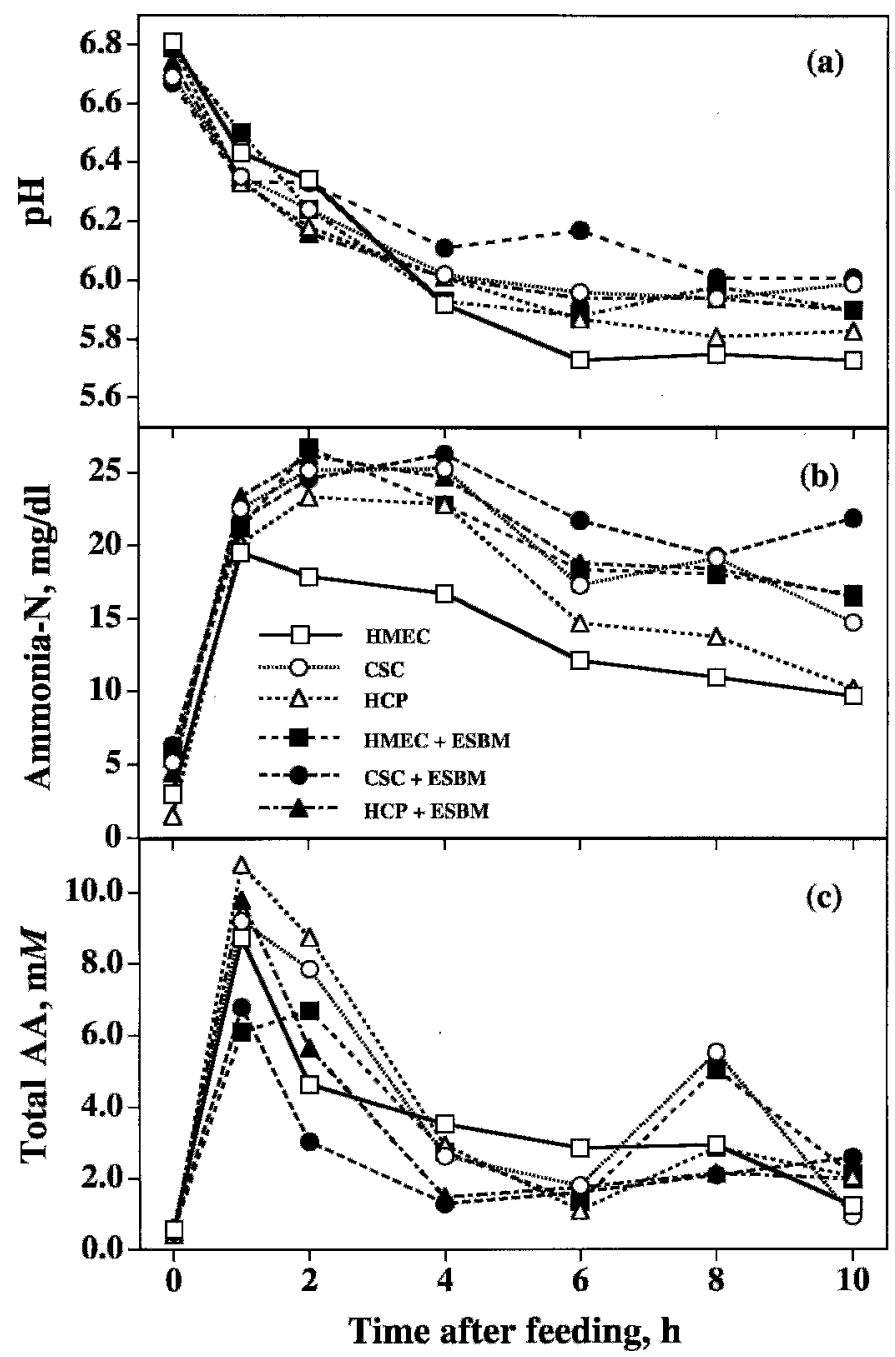

Figure 1. Mean ruminal a) $\mathrm{pH}$ (pooled $\mathrm{SE}=0.03$ ), b) $\mathrm{NH}_{3}$ concentration (pooled $\mathrm{SE}=1.1$ ), and c) total $\mathrm{AA}$ concentration (pooled $\mathrm{SE}$ $=0.35$ ) in cows fed alfalfa-silage based diets containing (DM basis): $38 \%$ high-moisture ear corn (HMEC); 39\% cracked shelled corn (CSC); $19 \%$ high-moisture ear corn plus 19\% dried citrus pulp (HCP); $27 \%$ high-moisture ear corn plus $12 \%$ expeller soybean meal (HMEC + ESBM); $27 \%$ cracked shelled corn plus $12 \%$ expeller soybean meal (CSC + ESBM); or 13\% high moisture ear corn, $13 \%$ dried citrus pulp, and $12 \%$ expeller soybean meal $(\mathrm{HCP}+\mathrm{ESBM})$.

nal contents was observed (contrast 1). Similar ruminal volumes, despite an average $1.7 \mathrm{~kg} / \mathrm{d}$ lower DMI on the HCP diets, suggested that gut fill may have restricted intake on the two diets containing DCP (Mertens, 1996).

\section{CONCLUSIONS}

The effectiveness of three dietary carbohydrate sources, HMEC, CSC, and a 50:50 mixture of HMEC plus DCP-fed without or with supplemental RUP from ESBM-was assessed in lactating dairy cows. When fed in TMR containing AS plus ryegrass silage, supple- menting ESBM increased DMI, yield of milk, FCM, fat, protein, lactose, SNF, and milk and blood urea concentrations, and decreased BW loss. Although there were no production differences between HMEC and CSC, DMI, yields of milk, FCM, fat, protein, lactose, SNF, and milk SNF content, all were lower or tended to be lower on the diets containing DCP. Milk protein and lactose content and blood glucose concentrations also were lower on HCP than on CSC. Ruminal ammonia and $\mathrm{pH}$, but not total AA and branched-chain VFA, were elevated by ESBM. Ruminal propionate was highest on HMEC diets and lowest on DCP diets; acetate, butyrate, and acetate-to-propionate ratio were lowest on HMEC diets and highest on DCP diets. These results indicated that, compared to HMEC and CSC, feeding the pectinrich feed DCP altered ruminal fermentation but depressed DMI and milk production.

\section{ACKNOWLEDGMENTS}

The authors thank Rick Walgenbach and the farm crew for harvesting and storing the feeds and Len Strozinski and the barn crew for in-animal care, BCS and sampling at the US Dairy Forage Center Research Farm (Prairie du Sac, WI); Brad Ricker, Mary Becker and Diane Amundson for conducting laboratory analyses; and Peter Crump for assisting with statistical analyses.

\section{REFERENCES}

Association of Official Analytical Chemists. 1980. Official Methods of Analysis. 13th ed. AOAC, Washington, DC.

Ben-Ghedalia, D., E. Yosef, J. Miron, and Y. Est. 1989. The effects of starch- and pectin-rich diets on quantitative aspects of digestion in sheep. Anim. Feed Sci. Technol. 24:289-298.

Broderick, G. A. 1986. Relative value of solvent and expeller soybean meal for lactating dairy cows. J. Dairy Sci. 69:2948-2958.

Broderick, G. A. 1995. Performance of lactating dairy cows fed either alfalfa silage or alfalfa hay as the sole forage. J. Dairy Sci. 78:320-329.

Broderick, G. A., and M. K. Clayton. 1997. A statistical evaluation of animal and nutritional factors influencing concentrations of milk urea nitrogen. J. Dairy Sci. 80:2964-2971.

Broderick, G. A., W. M. Craig, and D. B. Ricker. 1993. Urea versus true protein as supplement for lactating dairy cows fed grain plus mixtures of alfalfa and corn silages. J. Dairy Sci. 76:2266-2274.

Broderick, G. A., and J. H. Kang. 1980. Automated simultaneous determination of ammonia and total amino acids in ruminal fluid and in vitro media. J. Dairy Sci. 63:64-75.

Broderick, G. A., D. B. Ricker, and L. S. Driver. 1990. Expeller soybean meal and corn by-products versus solvent soybean meal for lactating dairy cows fed alfalfa silage as sole forage. J. Dairy Sci. 73:453-462.

Brotz, P. G., and D. M. Schaefer. 1987. Simultaneous determination of lactic and volatile fatty acids in microbial fermentation extracts by gas-liquid chromatography. J. Microbiol. Methods 6:139-144.

Choung, J. J., D. G. Chamberlain, P. C. Thomas, and I. Bradbury. 1990. The effects of intraruminal infusions of urea on the voluntary intake and milk production of cows receiving grass silage diets. J. Dairy Res. 54:455-464.

Crocker, L. M., E. J. DePeters, J. G. Fadel, H. Perez-Monti, S. J. Taylor, J. A. Wyckoff, and R. A. Zinn. 1998. Influence of processed 
corn grain in diets of dairy cows on digestion of nutrients and milk composition. J. Dairy Sci. 81:2394-2407.

Danfaer, A. 1994. Nutrient metabolism and utilization in the liver. Livest. Prod. Sci. 39:115-127.

Dijkstra, J., H. Boer, J. Van-Bruchem, M. Bruining, and S. Tamminga. 1993. Absorption of volatile fatty acids from the rumen of lactating dairy cows as influenced by volatile fatty acid concentration, $\mathrm{pH}$ and rumen liquid volume. Br. J. Nutr. 69:385-396.

Elizalde, J. C., N. R. Merchen, and D. B. Faulkner. 1999. Supplemental cracked corn for steers fed fresh alfalfa: I. Effects on digestion of organic matter, fiber, and starch. J. Anim. Sci. 77:457-466.

Ekinci, C. 1995. Effect of processing of high moisture corn on production and rumen parameters of dairy cows. M. S. Thesis, Univ. of Wisconsin, Madison.

Ekinci, C., and G. A. Broderick. 1997. Effect of processing high moisture ear corn on ruminal fermentation and milk yield. J. Dairy Sci. 80:3298-3307.

Faichney, G. J. 1986. The kinetics of the particulate matter in the rumen. Page 173 in Control of Digestion and Metabolism in Ruminants. L. P. Milligan, W. L. Grovum, and A. Dobson, ed. PrenticeHall, Englewood Cliffs, NJ.

Fegeros, K., G. Zervas, S. Stamouli, and E. Apostolaki. 1995. Nutritive value of dried citrus pulp and its effect on milk yield and milk composition of lactating ewes. J. Dairy Sci. 78:1116-1121.

Hall, M. B., W. H. Hoover, J. P. Jennings, and T. K. M. Webster. 1999. A method for partitioning neutral detergent-soluble carbohydrates. J. Sci. Food Agric. 79:2079-2086.

Hatfield, R. D., and P. J. Weimer. 1995. Degradation characteristics of isolated and in situ cell wall lucerne pectic polysaccharides by mixed ruminal microbes. J. Sci. Food Agric. 69:185-196.

Hintz, R. W., D. R. Mertens, and K. A. Albrecht. 1995. Effects of sodium sulfite on recovery and composition of detergent fiber and lignin. J. AOAC 78:16-22.

Hoover, W. H. 1986. Chemical factors involved in ruminal fiber digestion. J. Dairy Sci. 69:2756-2766.

Hristov, A., and G. A. Broderick. 1996. Synthesis of microbial protein in ruminally cannulated cows fed alfalfa silage, alfalfa hay or corn silage. J. Dairy Sci. 79:1627-1637.

Keady, T. W. J., C. S. Mayne, and M. Marsden. 1998. The effects of concentrate energy source on silage intake and animal performance with lactation dairy cows offered a range of grass silages. Anim. Sci. 66:21-33.

Knowlton, K. F., B. P. Glenn, and R. A. Erdman. 1998. Performance, ruminal fermentation, and site of starch digestion in early lactation cows fed corn grain harvested and processed differently. J. Dairy Sci. 81:1972-1984.

Leiva, E., M. B. Hall, and H. H. Van Horn. 2000. Performance of dairy cattle fed citrus pulp or corn products as sources of neutral detergent-soluble carbohydrates. J. Dairy Sci. 83:2866-2875.

Luchini, N. D., G. A. Broderick, R. E. Muck, N. F. Makoni, and R. L. Vetter. 1997. Effect of storage system and dry matter content on the composition of alfalfa silage. J. Dairy Sci. 80:1827-1832.
McDonald, P., A. R. Henderson, and S. J. E. Heron. 1991. The Biochemistry of Silage. J. Wiley and Sons, New York.

Mertens, D. R. 1996. Methods in modelling feeding behavior and intake in herbivores. Ann. Zootech. (Paris) 45(Suppl. 1):153-164.

Muck, R. E. 1987. Dry matter level effects on alfalfa silage quality. I. Nitrogen transformations. Trans. ASAE 30:7-14.

Nagel, S. A., and G. A. Broderick. 1992. Effect of formic acid or formaldehyde treatment of alfalfa silage on nutrient utilization by dairy cows. J. Dairy Sci. 75:140-154.

National Research Council. 2001. Nutrient Requirements of Dairy Cattle. 7th rev. ed. Natl. Acad. Sci., Washington, DC.

Owens, F. N., R. A. Zinn, and Y. K. Kim. 1986. Limits to starch digestion in the ruminant small intestine. J. Anim. Sci. 63:1634-1648.

Peacock, F. N., and W. G. Kirk. 1959. Comparative feeding value of dried citrus pulp, corn feed meal and ground snapped corn for fattening steers in drylot. Fl. Agric. Exp. Stn. Bull. 616, Institute of Food Agricultural Sciences, University of Florida.

SAS User's Guide: Statistics, Version 6 Edition. 1989. SAS Inst. Inc., Cary, NC.

Sklan, D., R. Ashkenazi, A. Braun, A. Devorn, and K. Tabori. 1992. Fatty acids, calcium soaps of fatty acids, and cottonseeds fed to high yielding cows. J. Dairy Sci. 75:2463-2472.

Solomon, R., L. E. Chase, D. Ben-Ghedalia, and D. E. Bauman. 2000. The effect of nonstructural carbohydrate and addition of full fat extruded soybeans on the concentration of conjugated linoleic acid in the milk fat of dairy cows. J. Dairy Sci. 83:1322-1329.

Sutton, J. D., J. A. Bines, S. V. Morant, D. J. Napper, and D. I. Givens. 1987. A comparison of starchy and fibrous concentrates for milk production, energy utilization and hay intake by Friesian cows. J. Agric. Sci. (Camb.) 109:375-386.

Thilsted, S. H. 1985. Plasma glucose concentration and glucose turnover rate in the dairy cow in late pregnancy and early lactation. Z. Tierphysiologie Tierernaehrung Futtermittelkunde 53:1-9.

Tolkamp, B. J., I. Kyriazakis, J. D. Oldham, M. Lewis, R. J. Dewhurst, and J. R. Newbold. 1998. Diet choice by dairy cows. 2. Selection for metabolizable protein or for ruminally degradable protein? J. Dairy Sci. 81:2670-2680.

Valadares Filho, S. C., G. A. Broderick, R. F. D. Valadares, and M. K. Clayton. 2000. Effect of replacing alfalfa silage with high moisture corn on nutrient utilization and milk production. J. Dairy Sci. 83:106-114.

Van Horn, H. H., S. P. Marshall, C. J. Wilcox, P. F. Randel, and J. M. Wing. 1975. Complete rations for dairy cattle. III. Evaluation of protein percent and quality, and citrus pulp-corn substitutions. J. Dairy Sci. 58:1101-1108.

Williams, P. E. V., R. J. Fallon, G. M. Innes, and P. Garthwaite. 1987. Effects on food intake, rumen development and live weight of calves of replacing barley with sugar beet-citrus pulp in a starter diet. Anim. Prod. 44:65-74. 